\title{
THE REASON AND PRAGMATIC KNOWLEDGE: RETRIEVING THE INTEGRATIVE MEANING
}

\author{
Eugenia Bogatu*, ORCID ID: 0000-0002-4448-0558 \\ State University of Moldova, 60, Alexei Mateevici Street, Chișinău, Republic of Moldova \\ *Corresponding author: Eugenia Bogatu, bogatue@yahoo.com \\ Received: 10. 22. 2021 \\ Accepted: 01. 12. 2022
}

\begin{abstract}
In this paper, an analysis of multiple sens of pragmatic knowledge in the context of scientific research is analized. Knowledge has a major role, both in the development of a person, but also of the whole society. Today's society is a society of knowledge. Knowledge cannot evolve separately from information. The quantity and quality of information largely depends on its processing by artificial intelligence. The involvement of knowledge in the field of artificial intelligence is not possible without critical thinking. A knowledge society is not perceived without the involvement of researchers. They are those who promote and develop scientific knowledge. This type of knowledge is found in all areas of activity of the society. Hence the social responsibility of the scientists in the scientific context of direct activity.
\end{abstract}

Keywords: pragmatic knowledge, meaning, understanding, reason, critical thinking.

Rezumat. În acest articol este realizată o analiză a multiplelor sensuri pe care le are cunoașterea pragmatică în contextul cercetării științifice. Cunoașterea are un rol major, atât în dezvoltarea unei persoane, dar și a întregii societăți. Societatea din prezent este o societate a cunoașterii. Cunoașterea nu poate să evolueze separat de informație. Cantitatea și calitatea informației depinde în mare măsură de procesarea ei de către inteligența artificială. Implicarea cunoașterii în domeniul inteligenței artificiale nu este posibilă fără o gândire critică. O societate a cunoașterii nu este percepută fără implicarea cercetătorilor. Anume ei sunt cei care promovează și dezvoltă cunoașterea științifică. Acest tip de cunoaștere se regăsește în toate domeniile de activitate ale societății. De aici derivă și responsabilitatea socială a savanților în contextul științific de activitate nemijlocită.

Cuvinte cheie: cunoaștere pragmatică, sens, înțelegere, rațiune, gândire critică.

\section{Introduction}

The pragmatic competence manifested in philosophy is related to an expressive manifestation of the thoughts that human thinking manifests, in the same way the pragmatic competence refers to the study of the ways in which thinking is involved and interacts with language. In this sense, the cognitive experience, the cognitive capacity, the communicative competences are of great importance. The specificity of the pragmatic competence valid for 
knowledge is fully found in the communicative competence [1]. It is difficult to dissociate between cognitive competence and communicative competence. Both are found and constitute an integral whole. These types of skills help us to better understand human behavior through its acts of communication and how certain extra linguistic elements have a decisive persuasive role in determining the senses and meanings that people transmit to others. The transmission of the meanings in question is done depending on the ability of the participants in a communication situation to understand at a fair value the meaning of what is heard. Of course, the subjective capacity to understand and explain what is heard is different from case to case. There are largely factors involved in the individuality of each person. The transmission of information in the communication process also depends on the conditions of truth that a statement must meet, but this criterion is not exclusive [2]. The pragmatic factor is also very important, not only for the truth of the statements, for the correspondence of their content with the things in reality, but also for the intention of the one who issues the statements, the way he issues them, the evaluation being a practicalinstrumental one.

\section{Knowledge related to communication}

The specificity of knowledge has always been characterized by the increase of added value in relation to what has been known up to the moment about an object, human being, process or event. From a metaphysical perspective, knowledge is oriented towards an abstract reality, guided by the foundations of a transcendental metaphysics [3]. This type of knowledge relates to the search for information about the object itself, about the limits of pure reason. Pure reason, absolutely, characterizes everything related to this type of metaphysics. Kant has created a string of interrogations and problematization situations regarding this type of knowledge. He was the philosopher who by excellence interrogated knowledge both from a metaphysical perspective and from a pragmatic perspective. The system of transcendental idealism created by Kant is a transcendental logic, as well as relating to a practical philosophy. In the plane of metaphysical knowledge, attention is paid to the full extent to the thing itself, which is researched within a system of knowledge. In the plane of practical knowledge, attention is paid to something in itself real and transcendental, outside the system. Knowledge in a pragmatic perspective is a matter of truth and justification. We can speak in this sense of a pragmatic theory of truth [4]. This theory concerns the truth that is determined by the contexts of action of people. In contexts where people direct their actions, existence is perceived in its practical way. This type of pragmatic view of realities goes beyond a kind of relativism generated by a number of changes that can intervene in any type of reality. „In sciences found on opinions and dogmas it is right to make use of anticipations and logic, if you wish to force assent rather than things" [5].

The speaker's intention is of great importance, because depending on this intention the statements are structured, their senses, meanings and finalities are created in the perspective of the subsequent actions at the level of verbal behavior. The understanding of the language depends directly on the acts of language through which the communication is made, on the real purpose of the communication, implicitly on the intention of the speakers, but also on the real context in which this communication situation is made. It is important that during the communication actions, depending on what is transmitted, the behaviors of the people participating in the communication situation are influenced or modified. Cognitive and communicative pragmatics appreciates communication and language as forms of human 
interaction. Language is of great importance in this context. Language comprehension depends on the acts of language through which the communication is made, the real purpose of the communication and the context in which it takes place. Pragmatics highlights everything that hides beyond textuality, because the deep meanings are in pre-text, con-text and sub-text. Thus, the person who reads or participates in direct communication must pay attention to the multitude of meanings of words that are found in one context or another. The meaning of the words transmitted in the communication acts influences the message of the transmitted ones, influencing the acts of practical conduct, the behavior of the people in the communication interaction.

The stake of the pragmatic approach is to explain how the behavior of people is influenced, even modified, through acts of communication. In the communication process, a series of factors interact that have the role of influencing the evolution of this process. Thus, the spectrum of pragmatic approaches also includes elements related to rhetoric, such as, for example, persuasion. Equally, there can be changes in values, attitudes, behaviors. In the communication, the implicit, the presuppositions are also fully manifested. All this leads to the field of metacommunication. Thus, the dialogue can always evolve depending on the series of assumptions related to the interlocutors participating in the dialogue. Human nature is formed in such a way that participation in communication acts is a creative act. A true hermeneutic game is established in communication and understanding of all its aspects. We can say that it is a true art of interpreting the intentions, presuppositions and implicit, these factors present in the context of communication situations. The communication situation is the basic element of social life. Beyond the finite number of words, which creates infinite meanings, people also resort to a series of significant and constant gestures. The gestural code represents a special semiotic language, which aims to complete the verbal language. Through this code, people strengthen their statements or negations. Semiotic language adds expressiveness to the series of words that people use in the communication process. We can say that between the participants in a communication situation a pragmatic relationship is created between the signs and the users of the signs. The ultimate goal in the communication process is to get people to act.

These actions belong to the sphere of changes at the level of attitude, mentality, and direct action in the context of the public sphere. We can deduce that communication is based on two competencies: the first refers to the ability to process the linguistic forms of expressions in order to reach their literary meaning, and the second competency refers to the ability to interpret the meanings of information transmitted in relation to those who they emit them and last but not least the context in which these communication situations occur.

We can say that each linguistic statement contains two classes of meanings: a linguistic meaning and a pragmatic meaning that derives from the determining conditions of the context in which the communication situation takes place. It is important for people to develop both these two types of skills throughout their lives, if the first type of competence, the linguistic one, is developed during institutionalized education, then pragmatic competence is most developed in the process of gaining experience, i.e. by virtue the multitude of communication situations that life generates, in all its complexity. Knowledge of the appropriate contextual use of the linguistic resources of a language is of great importance in the communication process. If there are shortcomings in this regard, then it will have to bear the consequences of the whole communication process, respectively the meanings that are transmitted. 


\section{Thinking and language - necessary interactions in the process of knowledge}

Knowledge, implicitly the process of rationalizing ideas, is not done in the absence of a language. From this point of view, a connection is created between thinking and language, a connection that represents a reference system between the reality of human language expressed in spoken or thought words and direct thinking, responsible for elaborating reasoning. The field that studies how our language gets involved and interacts with our thinking is represented by the philosophy of language. A mutual interdependence is created between thinking and speaking. Depending on the quality of spoken language, we can also appreciate the quality of thinking that underlies speech acts. Respectively, depending on the quality of thinking, we can also talk about the quality of speech. In this system of reference established between thought and speech, man is aided by logic. Studying logic, but also the relationship between logic and speech with certainty helps people to better structure their own arguments and to criticize the arguments of others. The meanings of the senses of words are due to the linguistic conventions established in the context of the space where one language or another is spoken. Equally important is the individual pragmatic competence, which makes the meanings and senses to acquire individual characteristics. The ways in which language interacts with the world are called reference theories. The sense of a sentence is the thought it expresses. The thought in turn is expressed in words. "A use of language, whether ordinary or complex, is not itself a feature or property of language acts any more than the type horse is a feature or property of horses" [6]. The senses determine the reference and are also the ways of presenting the objects to which the expressions refer. References are the objects in the world that the words speak of. Understanding language manifested in direct action, interpreting the multiple meanings that language has in different contexts, the connection between thinking and speaking is studied within the philosophy of language. This field explores the relationship between language and reality, especially the philosophy of language study issues that cannot be addressed by other fields. A great interdependence is created between the philosophy of language and philosophical logic. Thus, the nature of the sense rendered by the words we use in our internalized and externalized language represents the basic basis that is in the episteme of the philosophy of language. Language and the surrounding reality are the topics that are of major interest for the philosophy of language.

Knowledge, from this point of view, refers both to the ontic sphere that includes the entire objective reality, with all its components, but also to the sphere of language. The connection between language and reality represents a tandem of major importance for human existence, because man is characterized by his representation through language, respectively through his particular language and which renders the subjective matrix of the human being. We can rightly consider that language represents for man its system of reference, its spiritual axis and its cognitive matrix, logical alike. Apart from these determinations that naturally derive from the use of language, it is difficult to imagine human existence. We think and speak through language. We know through language. We interpret through the use of language. We have access to meanings transposed into and through language. The reality in which we live may be difficult, or impossible to perceive outside of language. We can say that language represents a different kind of reality; a subjective one thought and lived by the speaker. As is the nature and thought of the speaker, so is his language. Sensitivity, the refinement of human nature is represented through language, as well as the brutality, the marginalization of some people. The limits through which I represent 
this world to me are represented by language, and we can also say that the limits of our language represent the limits to which human thought has access through knowledge. The limitation given by language is also conditioned by the limitation given by knowledge. So, language and knowledge are mutually conditioned, they are two factors that depend on each other. Knowledge develops through language, and language in turn contributes to the rendering of everything that is assimilated new in the process of knowledge. As long as knowledge evolves, so will language. In general, the idea that a language is constantly evolving is valid, because it keeps pace with the process of knowledge, respectively does not stagnate. „An interpreter knows the conditions under which utterances of sentences are true, and often knows that if certain sentences are true, others must be" [7]. You know a society by the language it speaks, respectively by the linguistics they speak, respectively the researchers, the great creators of artistic and scientific language, resort to them. A language is put to work, respectively a language becomes, transforms in time, acquires new valences of use. Pragmatic competence is what helps us to use language efficiently in an appropriate context. This type of competence is a fundamental aspect of a communicative competence. One type of competence influences the other. So, pragmatic competence helps us to use language effectively to achieve a specific goal and to understand a language in context. A language is always used intentionally. The recourse to linguistic acts is always based on one intention or another. Pragmatic competence places language within the institutional framework of its use. The linguistic means to which we resort help us to realize our intentions at the level of language. So, a language offers us its linguistic tools for knowledge. This forces those who use one language or another to know not only the structure of that language, but also to know how to use it.

The pragmatic competence of the language is related to the recourse to a series of strategies related to the capacity of adaptability, evidence, dynamism, negotiation at the level of language. So, we can speak of a pragmatic communicative competence that comes with the presupposition that we have to adapt to the communication register of the other. Adaptability, flexibility in the context of dialogue has a great significance, because it targets the sphere of connection between the actors participating in the dialogue. During the communication, respectively the issuance of linguistic acts by one speaker for another speaker, there is a change in the mind of the other under the influence of the information transmitted by the corresponding linguistic acts. In the communication process, information is always transmitted that influences the dynamics of the other's mind. So, in this sense we can talk not only about pragmatics, but also about neuropragmatics. Speakers often aim to use language to achieve a specific purpose, depending on the topic, the communication register, the language tools. A communication register in which a communication situation takes place always has unlimited possibilities, because there is the possibility to negotiate pragmatic choices every time as the interaction takes place in order to fulfill the communicative intentions. Equally, the communicative interaction develops over time, because it requires adaptability and flexibility from the participants in the dialogue, but also the ability to understand how the other's mind works. The effects that a language has on one's mind is very great. Words produce major effects on the minds of those who hear, read these words, hence a series of effects - changes in moods, attitudes, actions, etc. So, the wordthought relationship is not only in the focus of the philosophy of language, but also a problematic situation for the philosophy of mind. Thus, spoken or written words, rendered or tacit thoughts, emotions that appear as an impact of these influences are basic components 
of the philosophy of language, as well as of the philosophy of mind. It is very important in this way to understand and appreciate at fair value everything that happens in the frame of reference of the philosophy of language and the philosophy of mind. Hermeneutics and semiotics, which aim to interpret the meanings transposed in and through language, also enter this frame of reference. Aspects of the context in which a communication situation takes place are of great importance and relevance for understanding the intentions projected in the messages transposed in the communication.

Communicative pragmatics relates more to understanding meanings, to understanding research compared to the production of language. The pragmatic approach in the case of semiotic analyzes of communication is made from the perspective of analysis of communication as a mode of action. Meanings in the context of communication arise from the use of words through language games. The use of words in communication is a real art, it involves creativity and authenticity. The meanings are created ad-hoc, by interweaving the meanings that in turn contribute to the emergence of ideas. When we talk about meanings, we must consider both the use of denotative language and the use of connotative language. There are two types of languages used in communication. If in the case of the use of denotative language the meanings are ordinary, banal, they relate directly to the immediate ontic sphere and do not bring any add of creative value for the enrichment of the language, then in the case of the connotative language the meanings are creative, they derive from the context, from the personal experience of the speakers, respectively the connotations enrich the linguistic, hermeneutic universe of the speakers.

\section{Critical thinking as a mode of action in the context of knowledge}

Critical thinking is very important in communication situations. Proper understanding and reception of messages requires the use of critical thinking tools. These tools allow a mapping of how each person thinks in relation to their own decisions. Those decisions can affect his life, attitude, mentality, behavior not least. Most of the time we appreciate, for better or worse, the choices, the human behaviors. Each person develops during his life a certain mental pattern, which determines everything he thinks, the way a certain person acts in one situation or another. Beyond certain elements that are universally valid for all people, each of them has developed a certain way of being, of rationalizing. These things are related to the construction and dynamics of the human brain, but also to the educational context in which that person was formed, to the external influences that influenced him during his life in one situation or another. Critical thinking is, in fact, authentic thinking based on judgments of appreciation, on reasoning. We can speak in this sense of the existence of a mental map that would ensure a good functioning of the human thinking system. And this mental map would represent both at an objective level and at a subjective level the entire human experience accumulated up to that moment. The importance of critical thinking in human life is overwhelming, because only in totalitarian societies this type of thinking has been rejected, its formation is not accepted. The consequences of the lack of this type of thinking at the level of society, or at the level of individual life are obvious. Rationalization and critical thinking are creative and imaginative processes in developing the arguments needed to support a cause, they involve emotional attitudes, but also communication skills. Critical thinking contributes to the fact that the information, respectively the meaning of what is communicated is not distorted. This type of thinking aims to promote the development of a matrix of thinking that would contribute to the fact that human thinking is as evolved as 
possible, authentic. Practicing critical thinking is also a practice of developing argumentation skills. It is very important to develop critical thinking skills because this involves developing the skills to be creative in developing new opportunities to think freely, to see beyond the limits imposed by the social context, implicitly the acceptances of others, their own prejudices and stereotypes. thinking. So, critical thinking aims at a mental activity to acquire knowledge about the world around, to base on rational arguments decisions about the world of things and actions, different from emotional attitudes towards human things or actions.

We can say that critical thinking is a metacognitive skill, a kind of thinking about thinking. This type of thinking is thinking more deeply about thinking, or thinking thinking. Correct thinking is very important in the process of knowing. The ability to think critically is acquired like many other skills. Three important elements are needed to develop this ability: knowledge, skills and attitude. Correct thinking is formed along the way, following a series of exercises in thinking operations. Critical thinking is needed to gain more objective knowledge. During correct thinking, the exact rules of thinking are followed, such as logical laws, methods of scientific reasoning. During critical thinking, knowledge is validated, it is subject to verification, proof, doubt. The principle of doubt has a great significance because it subjects knowledge, the process of knowing to an interrogation. Resistance to this interrogation means true knowledge, respectively truthful knowledge. It is also very important to detect errors that are encountered in a natural way in the process of knowledge. Critical thinking also requires the ability to engage in a reflective and independent thinking process. A person with critical thinking skills should be able to understand the logical connections between ideas; identify and build the necessary arguments; to reflect on what motivates personal beliefs and values. Developing good critical thinking skills requires more than just knowledge and practice. It also requires motivation and personal attitude to persevere in the development of critical thinking. There are also certain obstacles that hinder the natural development of critical thinking. These obstacles are represented by prejudices, stereotypes, false beliefs. There are enough cases when some people refuse to think too much about personal decisions, he says nd that it is based more on personal intuition. It is also difficult when people refuse to analyze the mistakes they have made. All this is just an impediment to correct thinking. It is very important for people to be aware of these mistakes and to avoid them in order to advance towards new ascents of authentic knowledge, respectively of authentic thinking.

The development of critical thinking is directly related to the development of imagination. In turn, the imagination is about creativity, respectively we need critical thinking to guide and moderate it. Creative thinking skills are important because they help to develop more ideas. Thus, when there are several ideas about one fact or another, there are more chances for there to be the best idea among several ideas. We can say that creative thinking skills are those that stimulate the critical, implicit and creative thinking process. When we refer to the development of critical thinking, we mean problem solving; finding solutions that require creativity; identifying ways that have not been considered; changing the interpretation of our perception of an event, a situation, a behavior, a person; the mapping of the mind which thus allows the generation of ideas in an associative way and which will represent an integral whole. Fundamental critical thinking strategies such as comparison, contrast, analysis, classification and evaluation can help and guide us to make the right decision. These strategies are both tools for critical thinking and help develop critical thinking skills. This type of critical thinking is in fact authentic thinking, able to contribute to the 
development of the human being in general, implicitly to the development of the mentality. The whole society is at an advantage when people are concerned with the development of this type of thinking. The level of development that a society has can be appreciated according to the level of thinking that the people who represent that society have.

\section{Knowledge and reality of the present time}

In recent decades, knowledge relates to a series of realities related to the relationship between science and technology. All ongoing processes are related to advances in information knowledge. We can say that science and technology have emphasized their systematic character. A series of achievements of the reality related to the sphere of information sciences have become applications in different fields, valid both for the sphere of exact, empirical sciences, but also for the sphere of socio-humanities. Today, there are almost no delimitations between research categories, between research issues. The degree of interdisciplinarity in the fields of research has increased. In this sense, it has become important to increase the obvious interest for a series of inter and transdisciplinary research. We can say that scientific knowledge is currently seeking to solve problems that society proposes to solve. From here, it naturally derives the social responsibility that scientists have when they assume the right to solve the problems that arise. "The search for hidden assumptions and fundamental premises is actually part of a larger enterprise" [8]. Knowledge has acquired new meanings and meanings compared to the paradigms that dominated knowledge in previous eras. Knowledge is not only a mental process, but also a process of artificial intelligence systems, industrial, economic and social organizations. "I want to suggest that this provides a perfectly ordinary model for explaining the puzzling relationships between the mind and the brain" [9]. One of the most interesting and current aspects of knowledge today is the artificial knowledge of expert systems, intelligent agents, ie artificial intelligence systems. Such elements have not yet been integrated into a new and appropriate theory of knowledge. Articular intelligence has become one of the types of intelligence that is of particular interest to researchers. This type of intelligence is of interest to computer scientists, mathematicians, but also to biologists, philosophers, psychologists, etc. Knowledge today is impossible to represent outside of all that is involved in artificial intelligence. Natural and artificial intellect are for many researchers the stake of research in current and future projects. The intellect is the main means used by man to survive and, especially, to advance in relation to his own self-knowledge. In the absence of the intellect man would be unable to survive.

We can say that there is no human activity from which intellectual activity would be excluded. This type of activity is an activity with several levels of complexity. At the first level it means knowledge, and at the second, creative thinking. Knowledge is one of the fundamental needs of man and aims to explain the world, and increasing knowledge brings value to society as a whole. Research activity, based on creative thinking, is the main factor of intellectual activity. The materialization of creative thinking contributes to the realization of new technologies or to the continuous improvement of all categories of technical means, to the continuous improvement of all categories of technical means, to the increase of the degree of competitiveness on the international market. Knowledge brings with it new knowledge, theories, paradigms that contribute to a better interpretation of the world. To have knowledge means to possess explicit knowledge about facts, events, actions, theories, paradigms. In this sense, knowledge can be archived through sign systems, transmitted in 
different scientific and social contexts to be used. „Mind is a word. It belongs to everyday speech rather than the vocabulary of science and the most relevant branch of science - human psychology - has placed a peculiarly strong taboo upon its use" [10]. Knowledge, respectively knowledge is the reference system of people, in the absence of this reference system it is impossible to imagine people's lives. The implementation of the knowledge society involves both the use of existing knowledge and the expansion and deepening, through new means, of scientific knowledge and the truth about existence, as well as the dissemination of knowledge to all people. In the situation where knowledge is not only a mental process, but, with certain specific limits, it is also a process of artificial intelligence systems, it is necessary for man to substantiate knowledge by thinking, based on validarguments.

\section{Conclusion}

Contemporary society is characterized by type of pragmatic knowledge. This knowledge also relates to pragmatic competence. Pragmatic competence is cognitive and communicative. There is a close interdependence between knowledge-communicationaction. The process of rationalization of ideas has a great importance for knowledge, respectively for the transmission of ideas, explanation and understanding of their meanings. Critical thinking is a mode of action for the context of knowledge. We can speak in this sense not only of pragmatics, but also of neuropragmatics. There is a direct connection between the level of thinking of people and the level of development of a society. Knowledge always brings with it novelty, originality and creativity. The value of new knowledge lies in its ability to contribute to the development of the problems that a society puts forward. Research based on critical and creative thinking is equally the strength and energy of any society.

Acknowledgments. This article was developed within the framework of the project Epistemological approach to personal development and education for society: from transdisciplinary strategies to the pragmatic ends of the current society in the Republic of Moldova, cipher 20.80009.1606.08 State Programme (2020 - 2023).

\section{References}

1. Tiaoyuan Mao, Shanhua He. An Integrated Approach to Pragmatic Competence: Its Framework and Properties. SAGE Open April-June 2021: 1-13. DOI:10.1177/21582440211011472

2. Lorelli Nowell. Pragmatism and integrated knowledge translation: exploring the compatabilities and tensions. Nursing Open, 2015, Volume2, Issue 3, pp.141-148.

3. Luis Garicano, Yanhui Wu. Knowledge, Communication, and Organizational Capabilities. Organization Science 23(5):1382-1397.

4. Hudcová Šárka. Tools of Internal Communication from Knowledge Transfer Perspective. Journal of Competitiveness, 2014. Vol. 6, Issue 4, pp. 50-62. DOI:10.7441/joc.2014.04.04

5. Baskin W. Classics in education, New York, 1966.

6. Parkinson G.H.R. The theory of meaning, New York: Oxford University Press, 1968.

7. Guttenplan S. Mind and Language, New York: Oxford University Press, 1975.

8. Minton A. J. Shipka, Th. A. Philosophy: Paradox and Discovery, 1990.

9. Searle J. Minds, Brains and Sciens, Cambridge: Harvard University Press, 1984.

10. Scher J. M. Theories of the mind, New York: The Free Press of Glencoe, 1962. 